\title{
NEKATERE ZNAČILNOSTI FIZIČNE STRUKTURE SLOVENSKIH MEST
}

\author{
Vladimir Drozg*
}

\section{Izvleček}

Prispevek obravnava nekatere značilnosti fizične strukture slovenskih mest, in sicer urbanost grajene strukture, prometnic in javnih odprtih površin. Ugotovljeno je, da je urbanost $v$ večini mest slabo izražena, oziroma omejena le na ožje središče (v malih mestih) in širše središče (v srednje velikih in večjih mestih).

Ključne besede: Mesta, morfologija, urbana geografija

PHYSICAL STRUCTURE OF SLOVENE TOWNS

\begin{abstract}
Article deals with some characteristics of physical structure of Slovene cities, such as urbanism of built structure, of arterial roads and public open areas. It is established that in most cities urbanity being poorly manifested or limited only on narrower center (in small cities) and on wider center (in middle and bigger cities).
\end{abstract}

Key words: Towns, morphology, urban geography, Slovenia

* Dr., izred. profesor, Pedagoška fakulteta, Univerza v Mariboru, Koroška cesta 160, SI 2000 Maribor 


\section{UVOD}

Prispevek prikazuje značilnosti fizične strukture slovenskih mest, in sicer iz vidika urbanosti. Urbanost je $\mathrm{v}$ tem primeru vsebinski okvir, iz katerega $\mathrm{v}$ procesu interpretacije oziroma vrednotenja izhajamo. Seveda je umestno vprašanje, ali je urbanost ustrezen pojem za presojo fizične strukture, saj gre za zgodovinsko kategorijo, ki se v vsaki fazi razvoja mest (in družbe) kaže drugače. Razumevanje mest je namreč razpeto med več skrajnosti; med kulturološkim in progresističnim videnjem (po Choay), med regionalistično (lirsko) in geometrijsko racionalistično (dramatsko) usmeritvijo (po Mušiču), med geometrijskim in organskim pristopom (po Jacobs), med kompaktnim in disperznim mestom. V vsakem od teh kontekstov ima pojem "urbanost" osrednje mesto, le da se uresničuje na zelo različne načine. Zato je pomembnejše vprašanje, kako se urbanost $\mathrm{v}$ teh kontekstih izraža, oziroma, kako in $\mathrm{s}$ katerimi elementi lahko urbanost ponazorimo.

\section{KAJ JE URBANOST}

V osnovi pomeni "urbanost" nekaj, kar je specifično mestno. Pojem se nanaša na tri vsebine:

- socialno (poseben način življenja - individualnost, odtujenost, tolerantnost, občutek usodne povezanosti med ljudmi, socialno segregacijo in socialno heterogenost, javnost življenja),

- ekonomsko (poseben način preživljanja in dela - visoko stopnjo delitve dela, neodvisnost od naravnih razmer, terciarizacijo in naravnanost na storitvene dejavnosti, kar (v današnjem času) izpostavlja pomen znanja, informatike in medijev),

- fizično (posebnosti grajenega okolja, kakršnega določa morfološka raznolikost, gostota dejavnosti ter socialna heterogenost prebivalcev). Urbanost fizične strukture odgovarja socialni heterogenosti (zato je morfološko raznovrstna), koncentraciji prebivalstva in ekonomije (zato jo določa gosta zazidanost), visoki stopnji delitve dela (zato je polifunkcionalna), javnosti življenja (posledica tega je javni in zasebni prostor), neodvisnosti od naravnih razmer (govorimo o urbanizirani naravi in antropogenizaciji okolja) in simbolnosti prostora (od tod monumentalnost zazidave). Urbanost fizične strukture je posledica specifičnega življenja in ekonomije v mestu.

\section{KAKŠNA JE URBANA FIZIČNA STRUKTURA}

V nadaljevanju je navedenih nekaj stališč o urbanosti fizične strukture, ki se v teoriji pojavljajo najpogosteje in so relevantna še danes. Izvedena so iz funkcijskega, kulturološkega in ekološkega koncepta mesta, ideje sostrukturnosti in Lynchevih 
pojmovanj kvalitetne oblike mesta. ${ }^{1}$ Veljajo za srednjeveško, klasicistično in modernistično mesto. Za urbano fizično strukturo je značilno:

- Gostota zazidanosti, ki dosega vsaj $60 \mathrm{preb} / \mathrm{ha}$; (glede na majhnost slovenskih mest sem upošteval tudi $50 \mathrm{preb} / \mathrm{ha}$ ). Vse oblike zazidanosti takih gostot ne omogočajo. Zato veljajo kot urbani načini zazidanosti ulični blok, vrsta večstanovanjskih hiš, niz večstanovanjskih hiš in večji solitarni objekti. Načini zazidanosti, ki ne omogočajo minimalnih gostot, so manj mestotvorni oziroma za mesta manj primerni. Večja ko je površina zazidana z omenjenimi načini, bolj urbana bi naj bila struktura mesta.

- Objekti, ki omogočajo večje gostote, vzpostavljajo grajeni prostor, delujejo monumentalno in so tipološko enotni. Takšni so večstanovanjska hiša, blok in solitarni objekti. Po mnenju Curdesa je značilnost urbane fizične strukture majhen izbor osnovnih elementov, vendar so ti oblikovani in razmeščeni $\mathrm{v}$ številnih različicah (Curdes 1992 :76). Tudi Lefebvre meni, da je znak urbanosti način zazidanosti in oblikovanost zgradb (Lefebvre $1990: 128)^{2}$.

- Berljiv red in ustroj fizične strukture, iz katere bi naj bila razvidna urejevalska ideja. Pri mestu gre za transformirano okolje, ki bi naj bilo (pre)oblikovano s kompleksno idejo (lahko jo imenujemo red, preglednost, obvladljivost). Preprostejša ko je ideja oblikovanja, bolj so objekti razmeščeni po aditivnem principu, popolnejša kot je zasnova, bolj ima tloris značilnosti načrtnega, zavestnega delovanja.

- Orientacijske točke in vidni poudarki. Sittejev kulturološki pristop k urejanju mest izpostavlja mesto kot umetniško delo; tako govori o kulturni podobi mesta, katero jo tvorijo mestne palače, dolge in obzidane prometnice, prostrani trgi (Sitte 1997) ${ }^{3}$. Podobno razmišlja Lynch ko pravi, da mora ureditev mesta omogočati orientacijo in s tem mentalno obvladljivost mestnega prostora (Lynch 1992).

- Odprte javne površine, ki omogočajo socialne stike in so hkrati oskrbna središča.

- Prometnice ki so del bivalnega okolja, ne le prometnotehničnega sistema. Prometnice niso namenjene samo motornemu prometu, ampak tudi ljudem. Priljudnejši značaj daje orientacija objektov na ulico, kar omogoča polifunkcionalno rabo površin, obzidanost prometnic pa ločuje zasebni prostor od javnega ter omogoča stik med stanovanjem in dogajanjem na ulici.

- Oblikovna skladnost morfoloških elementov (merilo in oblika). Schirmacher pravi, da je merilo kvalitetne fizične strukture množica variant istega

\footnotetext{
${ }^{1}$ Pri tem se opiram na: J. Steinbach: Urbanität - Beitrage zu einem verhaltenstheoretischen und planungsbezogenen Konzept. V: Raumforschung und Raumordnung 3/1994 :212-221; K. Lynch: Good City Form. Cambridge: MIT 1992; A. Feldtkeller: Die Zweckentfremdete Stadt. Frankfurt: Campus 1994; H. Häussermann, W. Siebel: Neue Urbanität. Frankfurt: Suhrkamp 1987; W. Siebel: Was machte eine Stadt urban? V: Stadt und Mensch. Frankfurt: Peter Lang 1996; G. Curdes Stadtstruktur und Stadtgestaltung. Stuttgart: Kohlhammer 1992.

${ }^{2}$ Lefebvre H., Die Revolution der Städte. Frankfurt: Athenäums 1990

${ }^{3}$ Sitte C.; Umetnost graditve mest. Ljubljana: Habitat 1997
} 
morfološkega elementa, ki pa se razlikujejo po oblikovnih detajlih in položaju v prostoru (Schirmacher $1992: 113$ ).

- Polifunkcionalnost. Vsi deli mesta bi naj obsegali vse funkcije in ureditve, ki služijo zadovoljevanju človekovih potreb in so namenjeni bivanju $\mathrm{v}$ urbanem okolju. Polifunkcionalnost pomeni poleg razmeščanja funkcij še razmeščanje objektov javnega značaja po celotnem teritoriju mesta, pa tudi razmestitev osnovnih morfoloških elementov v vseh delih mesta (trgov, zelenih površin, vseh kategorij prometnic).

Pri oceni urbanosti slovenskih mest se bom omejil samo na izbrane element fizične strukture, in sicer način zazidanosti in gostoto prebivalcev, razmestitev in značilnosti trgov ter opremljenost prometnic. Kriteriji vrednotenja so prirejeni malim, srednje velikim in velikim mestom.

\section{RELEVANTNI ELEMENTI ZA VREDNOTENJE URBANOSTI FIZIČNE STRUKTURE}

$\mathrm{V}$ nadaljevanju je potrebno opredeliti kazalce in kriterije, na podlagi katerih lahko sklepamo o urbanosti fizične strukture. Odgovoriti je potrebno na vprašanje, kateri morfološki elementi izražajo urbanost oziroma kakšni bi le-ti naj bili? Pri tem izhajam iz konstitutivnih elementov mesta, ki fizično strukturo vzpostavljajo. Pomembna je tudi opredelitev vrednostne lestvice za ocenjevanje urbanosti. Opozoriti je potrebno da je kriterialni aparat za presojo fizične strukture je povsem subjektiven; $\mathrm{z}$ objektivnimi in z empirijo podprtimi merili ni mogoče ovrednotiti tako kvalitativnega pojma. Značilnosti fizične strukture smo presojali s opisnimi pojmi, kot so povprečje, delež površine, izjemno, redko, gostota, pogostost, prevladujoče.

Za oceno urbanosti so relevantni naslednji morfološki elementi:

Zgradbe:

- Način zazidanosti, ki vzpostavlja grajeni (urbani) prostor in omogoča primerne gostote. Način zazidanosti pomeni pomeni razmestitev in medsebojni položaj objektov. "Urbanotvorni" načini zazidanosti so ulični blok, vrsta večstanovanjskih hiš, stavbni kompleks in večji solitarni objekti. Merodajna je površina mesta $\mathrm{z}$ načini zazidanosti, ki omogočajo večje gostote. Znak pomanjkljive urbanosti pa so območja, kjer je gostota zazidanosti manjša (npr. območja s prostostoječo enodružinsko hišo). Predpostavljamo, da je minimalni prag gostote, ki ima urbana obeležja odvisen od velikosti mesta. Zato smo upoštevali kot "urbano" gostoto $80 \mathrm{preb} / \mathrm{ha} \mathrm{v}$ velikih mestih (nad 20.000 prebivalcev), $v$ srednejvelikih in malih mestih pa $60 \mathrm{preb} / \mathrm{ha} .{ }^{4}$

\footnotetext{
${ }^{4}$ Gostote so izračunane samo za stanovanjske dele mesta, brez površin z industrijo, infrastrukturo in rekreacijo.
} 
- Vrste zgradb, ki omogočajo primerne gostote in vzpostavljajo grajeni prostor. Relevantna je delitev na območja enostanovanjskih ter večstanovanjskih hiš, pri čemer je merodajna površina pozidanega območja, kjer prevladujejo večstanovanjske hiše (večstanovanjska meščanska hiša, trška hiša, blok, stolpnica). Območja prostostoječih enostanovanjskih hiš pa veljajo za manj urbanotvorna.

- Nadstropnost je delno že zapopadena v vrsti zgradbe, posredno pa kaže stanovanjsko gostoto. Za natančnejšo predstavo o urbanosti smo upoštevali območja, kjer prevladujejo do tri etažni objekti in območja, kjer prevladujejo objekti višji od treh etaž. Dodatno smo v velikih mestih opredelili še območja s pet etažnimi objekti.

Prometnice:

Relevantni so elementi vzdolžnega in prečnega profila, ki različno vzpostavljajo grajeni prostor. Med elementi prečnega profila so urbanotvorne naslednje značilnosti:

- Obzidane in ograjene prometnice ${ }^{5}$ bolje vzpostavljajo grajeni prostor kakor neobzidane prometnice. Ta kazalec je relevanten samo v stanovanjskih predelih mest in pri prometnicah, ki niso prvenstveno namenjene motornemu prometu, kot npr. tranzitne ceste, obvoznice, mestne hitre ceste. Merodajna je dolžina obzidanih in ograjenih prometnic napram dolžini neobzidanih prometnic oziroma prevladujoč značaj prometnic $\mathrm{v}$ mestu. $\mathrm{V}$ velikih mestih delujejo mestotvorno obzidane in ograjene prometnice, ki potekajo skozi območja centralnih dejavnosti, npr. trgovske ulice, vpadnice. Zato smo jih opredelili posebej.

- Prometnice s hodniki za pešce in drevoredom imajo elemente bivalnega okolja in več predispozicij za socialne stike in javnost odprtih površin. Merodajen je delež prometnic $\mathrm{s}$ hodniki za pešce napram ostalim prometnicam.

- Ukrivljene (zavite) prometnice so oblikovni element stanovanjskih območij, saj so ambientalno slikovite. Ker so posledica načrtnega ravnanja, izkazujejo težnjo po oblikovanju bivalnega okolja. Merodajen je delež (pogostost) ukrivljenih prometnic $\mathrm{v}$ stanovanjskih območjih.

Odprte javne površine:

Ker so javne površine pomemben mestotvorni element, smo opredelili več kazalcev:

- Diferenciranost trgov. Trgi so funkcijsko diferencirani, če je posamezen trg namenjen pretežno eni dejavnosti. V tem smislu ločimo parkovni, prometni, spominski, upravni, trgovski in cerkveni trg. Specializiranost trgov pomeni raznovrstnost prostora in s tem večjo urbanost.

- Hierarhija trgov kaže razmestitev in njihov mestotvorni pomen. V vsakem delu mesta bi zato naj obstajal trg oziroma izoblikovan prostor, kjer so možni socialni

\footnotetext{
${ }^{5}$ Prečni profil obzidane prometnice je sestavljen iz cestišča in hodnikov za pešce, pri ograjeni prometnici je med cestiščem in zgradbo zelenica, omejena $\mathrm{z}$ ograjo, pri neobzidani prometnici pa je med cestiščem in zgradbo nepozidan, običajno zazelenjen prostor.
} 
stiki. Trgov najnižje ravni bi moralo biti največ, najvišje ravni pa najmanj. Bolj ko je hierarhija trgov izoblikovana, večja je stopnja urbanosti. S tem je povezana tudi razmestitev oziroma dostopnost do javnih odprtih površin. 700 metrski radij dostopnosti do trgov bi naj prekril vsa stanovanjska območja mesta.

- Parkovne površine. Antropogenizirana narava je imanenten element urbanosti fizične strukture, še posebej če upoštevamo socialno, oblikovno in ekološko funkcijo zelenih površin. Razmestitev, površina parkov ter dostopnost v $1000 \mathrm{~m}$ radiju so zato primerni kriteriji urbanosti.

Obstaja še vrsta drugih elementov, ki prav tako ponazarjajo fizično strukturo mesta (npr. število in velikost centralnih območij, dolžina trgovskih ulic, nepozidane in proste površine, degradirane površine), vendar so za vrednotenje urbanosti manj primerne.

\section{MORFOLOŠKE ZNAČILNOSTI SLOVENSKIH MEST}

Spoznanja o urbanosti fizične strukture izhajajo iz kartiranja 27 mest. Urbanost fizične strukture smo presojali v dveh korakih. V prvem smo kartografsko prikazali značilnosti in razmestitev morfoloških elementov, ki določajo urbanost fizične strukture. V drugem koraku pa smo opredelili dele mesta, kjer je urbanost bolj izražena in območja, kjer je urbanost pomanjkljiva ali je premalo izrazita. Pri tem smo izhajali iz predpostavke, da je urbana fizična struktura preplet vseh konstitutivnih elementov mesta, torej hiš, prometnic in javnih odprtih površin (oziroma kazalcev, ki kažejo njihove urbane značilnosti). Urbanost enega od morfoloških elementov še ne pomeni urbanosti celotnega (dela) mesta; urbane značilnosti morajo imeti vsi konstitutivni elementi. ${ }^{6}$ Glede na koncentracijo in sovpadanje urbanih značilnosti morfoloških elementov smo razlikovali med deli mesta $\mathrm{z}$ bolj oziroma manj izraženo urbanostjo.

\section{Urbanost grajene strukture}

1. Območja z načini zazidanosti, kjer so gostote večje od 80 oziroma $60 \mathrm{preb} / \mathrm{ha}$, so majhna, omejena na posamezne "stavbne otoke". V velikih mestih obsegajo slabo polovico pozidane površine, $\mathrm{v}$ srednjevelikih mestih med četrtino in tretjino, $\mathrm{v}$ malih mestih pa je delež pod desetino pozidanega teritorija. Najpogosteje se pojavljajo blokovni kompleksi, solitarni objekti, vrste večstanovanjskih in trških hiš (v srednjevelikih mestih) ter ulični blok (le v treh največjih mestih). Največji

\footnotetext{
${ }^{6}$ Urbanost pomeni prostorske ureditve, kjer je prostor zavestno spreminjen $\mathrm{v}$ celovito, funkcionalno in estetsko urejeno okolje. Pri tem gre za transformacijo prvobitne narave $\mathrm{v}$ antropogenizirano okolje, ki omogoča zadovoljevanje človekovih potreb in življenje $\mathrm{v}$ skupnosti; kompleksnejša je ideja transformacije, bolj izrazita je urbanost.
} 
del mest zavzemajo območja enodružinskih prostostoječih hiš. V malih mestih je velik delež takega načina zazidanosti še razumljiv, predvsem v srednjevelikih in velikih mestih pa povsem nesprejemljiv. Blokovske soseske so zaprte, introvertirane, nepovezane $\mathrm{z}$ okoliškim prostorom. Polifunkcionalnost prostora je omejena, funkcija prometnice kot javne površine in element bivalnega okolja pa ni vzpostavljena.

2. Povprečna gostota zazidanosti v slovenskih mestih je primerna in znaša med 100 in $150 \mathrm{preb} / \mathrm{ha}$. Vendar so znotraj posameznih delov mest razlike zelo velike. Tako je v blokovnih kompleksih gostota tudi preko 300 preb/ha (običajno okoli $250 \mathrm{preb} / \mathrm{ha}$ ), v območjih prostostoječih enodružinskih hiš pa le okoli $40 \mathrm{preb} / \mathrm{ha}$. Velika povprečna gostota je posledica višje etažnosti v blokovnih kompleksih, ki so sicer oblikovno sporen element. Območja višje etažnosti namreč marsikje prevladajo nad malim merilom slovenskih mest in vizualnimi dominantami, ki so zaenkrat skoncentrirane v srednjeveškem delu mesta. Kot ugotavlja Pogačnik, so "kontrasti v višinah le redkokje nova oblikovna mestna kakovost - največkrat gre za bolečo spremembo merila ter za izgubo značilne silhuete" (Pogačnik 1996 :200).

Slika 1: Murska Sobota: Prostostoječe enodružinske stanovanjske hiše zavzemajo skoraj $80 \%$ površine stanovanjskih območij

3. Takšne razmere potrjuje tudi površina mesta, pozidana $\mathrm{z}$ enostanovanjskimi in večstanovanjskimi hišami, ki je tudi pri srednejvelikih mestih povsem na strani enostanovanjskih hiš, v malih mestih pa so enostanovanjske hiše skoraj edini način zazidanosti. Tudi pri velikih mestih so enostanovanjske hiše v širšem središču mesta, kar kaže ekstezivno rabo zemljišč. 
4. Prevladuje aditivni tip tlorisa, ki vsaj za del mesta zgrajen $\mathrm{v}$ drugi polovici tega stoletja, pomeni manj celovito, celo stihijsko zazidanost. Območja $\mathrm{s}$ kompleksnejšo idejo oblikovanja prostora so zelo redka. Zato ne preseneča veliko urbanistično degradiranih površin, kjer je prometno omrežje nefunkcionalno, kjer primanjkuje oblikotvornih prvin ali je pomanjkljiva urbana oprema (Koželj 1998). Na robovih mest je pogost pojav razpršene gradnje, kjer so stanovanjske gostote tudi pod $30 \mathrm{preb} / \mathrm{ha}$. Zaradi takšnega načina zazidanosti je fizična struktura malih mest enaka strukturi obmestnih naselij.

5. Načini zazidanosti in vrste objektov so značilni predstavniki določenega obdobja gradbene zgodovine mesta. Za srednjeveško mesto so značilne trške hiše, postavljene $\mathrm{v}$ vrsti, za meščansko obdobje so značilne večstanovanjske hiše, postavljene $\mathrm{v}$ uličnem bloku ali $\mathrm{v}$ vrsti, vile ter prostostoječe delavske hiše, za modernistični tloris so najznačilnejši bloki in prostostoječe enodružinske hiše. Uličnega bloka iz najnovejšega obdobja gradbene zgodovine in zasnovanega $\mathrm{v}$ modernistični maniri v slovenskih mestih ni, tudi vrstnih večstanovanjskih hiš ne (redke izjeme so le v treh večjih mestih). Zelo malo je primerov, da bi v obdobju modernega urbanizma nastala zazidava, značilna za pretekla obdobja gradbene zgodovine (npr. ulični blok, večstanovanjske hiše). Takšne razmere so posledica uveljavljenega ekspanzivnega širjenja mest in gradnje blokovnih sosesk. Prevladovalo je širjenje na robu mesta, zapolnjevanje, prenova in prestrukturiranje degradiranih območij je bilo veliko redkejše.

\section{Urbanost prometnic}

1. Posledica prikazanega načina zazidanosti je velik delež ograjenih in neograjenih prometnic, ki so manj urbanotvorne. Obzidane prometnice so samo v delih mesta $\mathrm{s}$ srednejveškim in klasicističnim tlorisom, sicer pa prevladujejo ograjene in neograjene. Le redke vpadnice $\mathrm{v}$ velika mesta ter prometnice $\mathrm{v}$ širšem središču so obzidane in tako dolge, da imajo izrazit urbani značaj. V malih in srednjevelikih mestih so dovolj urbane le prometnice $\mathrm{v}$ najožjem središču.

2. Prečni profil prometnic $\mathrm{v}$ stanovanjskih območjih je večinoma skromen. $\mathrm{V}$ velikih mestih je prometnic s hodniki za pešce in zelenicami bistveno več kot $\mathrm{v}$ malih mestih, čeprav so pločniki urejeni predvsem na prometno bolj frekventnih prometnicah, manj pa na dovoznih cestah v stanovanjskih območjih. Še redkejše so prometnice $\mathrm{z}$ drevoredi. $\mathrm{V}$ srednjevelikih mestih je $\mathrm{v}$ povprečju le $10 \%$ prometnic $\mathrm{z}$ drevoredom ali zelenico in le $40 \%$ prometnic s hodnikom za pešce. Največ elementov urbanosti imajo prometnice $\mathrm{v}$ klasicističnem delu mesta, novejše pa so zasnovane kot del tehničnega sistema, ne pa bivalnega okolja.

3. Zavitih prometnic $\mathrm{v}$ stanovanjskih območjih pravzaprav ni. Tam kjer se pojavljajo, se prilagajajo topografiji ali lastništvu parcel, in niso rezultat načrtnega oblikovanja $\mathrm{z}$ namenom povečevanja ambientalne atraktivnosti. Ugotavljamo celo nasprotno, v soseskah enodružinskih hiš je prometno omrežje nefunkcionalno, kar je posledica premalo načrtnega razvoja. 


\section{Urbanost javnih odprtih površin}

1. Trgi so najpogostejši v srednejveških mestih, v novejših delih pa so zelo redki. Po eni strani je to odraz velikosti mest, saj je večina oskrbnih in storitvenih dejavnosti nameščena $\mathrm{v}$ najožjem središču mesta. Po drugi strani pa je to odraz razumevanja in urejanja mesta, ki je omejeno le na zagotavljanje stanovanj, ne pa na urejanje spremljajočih dejavnosti, med katerimi so tudi javne odprte površine. $\mathrm{V}$ velikih mestih so obsežni predeli brez trgov, le z oskrbnimi središči, ki so sodobna različica trgov $\mathrm{v}$ funkcijskem smislu, $\mathrm{v}$ morfološkem in socialnem pa prav gotovo ne. Vzpostavljajo jih objekti z oskrbnimi in storitvenimi dejavnostmi ter parkirne površine. Nekdanja socialna funkcija trgov je dobila v novih delih mest pomen tehnicističnih vozlišč.

2. Ker je trgov razmeroma malo, je diferenciacija slabo izražena. Trgi s posebno namembnostjo se pojavljajo izjemoma, pa še to le v velikih mestih. Prevladujejo trgovski, cerkveni in prireditveni trgi, ki imajo tudi značaj osrednjega trga. Srednjeveški trgi imajo večinoma trgovsko funkcijo, trgi iz klasicističnega obdobja so običajno parkovni ali spominski, trgi iz najnovejšega obdobja pa imajo večinoma prometno funkcijo (križišča ali parkirišča).

3. Hierarhija trgov je slabo izražena. Trgov v sosedstvih, katerih bi moralo biti največ, je v resnici najmanj. Tudi središča mestnih četrti so slabo izražena, večinoma jih ni. Za mala mesta velja, da imajo samo en trg, ki je hkrati osrednji prostor. Hierarhija je izražena le $\mathrm{v}$ večjih mestih. Trgi različnih hierarhičnih stopenj so le v srednjeveških delih mest, v novejših območjih pa manjkajo trgi mestnih četrti in stanovanjskih okolišev.

4. Oprema trgov ne vzpodbuja socialne funkcije. Večina je namenjenih parkiriščem, prostor za pešce pa je omejen. Tudi oblikovna oprema trgov je skromna; skulpture, vodnjaki, vegetacija in parkovne ureditve so redek element $\mathrm{v}$ trgih mest; še posebej tistih iz novejših obdobij.

5. Parkovnih ureditev je $\mathrm{v}$ slovenskih mestih zelo malo, $\mathrm{v}$ malih mestih antropogenih zelenih površin sploh ni. Po svoje je to razumljivo, saj je življenje v malih mestih še tesno povezano $\mathrm{z}$ naravo. Večina parkovnih površin je $\mathrm{v}$ srednjeveških in klasicističnih predelih, kjer so urejeni drevoredi in manjši parki. Parkovnih ureditev iz najnovejšega obdobja v slovenskih mestih ni! Javne zelene površine kot morfološki element in element bivalnega okolja se še niso uveljavile. Tam, kjer je demografsko težišče mesta, je zelenih površin najmanj. Parkovnih trgov skoraj ni, stanovanjske soseske pa so opremljene zgolj s posamičnimi drevesi in otroškimi igrišči.

\section{Urbanost slovenskih mest}

S prekrivanjem grafičnih prikazov urbanosti grajene strukture, prometnic in javnih odprtih površin, se pokažejo deli mest, kjer je urbanost bolj izražena in predeli, kjer 
fizična struktura nima urbanega značaja. ${ }^{7}$ Pokaže se, da je urbanost bolj izrazita $v$ velikih mestih kakor v malih (seveda obstajajo tudi izjeme), v katerih je več načrtno zgrajenih stanovanjskih predelov in več tipov tlorisov. Razlike $\mathrm{v}$ deležih površine $\mathrm{z}$ dovolj izraženo urbanostjo so pravzaprav prevelike, saj je razpon od 25 do $80 \%$ pozidane površine, v povprečju pa je urbanotvornih površin tudi le polovica.

Slika 2: Slovenj Gradec - del mesta z bolje izraženo urbanostjo je omejen na središče mesta

Preglednica: Delež pozidane površine (brez industrijskih območij) izbranih mest, kjer je urbanost fizične strukture dobro izražena (v \%)

\begin{tabular}{|l|c|l|c|}
\hline Koper & 84 & Krško & 42 \\
\hline Nova Gorica & 76 & Slovenske Konjice & 42 \\
\hline Izola & 75 & Ormož & 38 \\
\hline Velenje & 67 & Kočevje & 36 \\
\hline Tolmin & 66 & Kamnik & 35 \\
\hline Maribor & 65 & Domžale & 31 \\
\hline Postojna & 65 & Slovenska Bistrica & 31 \\
\hline Kranj & 62 & Ljutomer & 30 \\
\hline Celje & 61 & Radovljica & 29 \\
\hline Škofja Loka & 54 & Ajdovščina & 27 \\
\hline Slovenj Gradec & 51 & Brežice & 25 \\
\hline Ptuj & 48 & Črnomelj & 23 \\
\hline Novo Mesto & 45 & Dravograd & 22 \\
\hline Murska Sobota & 44 & & \\
\hline
\end{tabular}

\footnotetext{
${ }^{7}$ Ker je vrednotenje tako kvalitativnega pojava silno težavno, smo se omejili samo na dve vrednostni obliki, in sicer dobro in slabše izražena urbanost fizične strukture.
} 
Največ urbanih značilnosti je v ožjih središčih mest (velja za mala mesta) ter širših središčih mest (velja za srednje velika mesta). V velikih mestih je urbanost očitna na večini pozidane površine, razen na robu mesta in nekaterih območjih enostanovanjskih hiš, nastalih v 30 tih letih in po letu 1970. Skoraj brez izjeme so najbolj urbanotvorni srednjeveški deli mest, novejši pa zaradi pomanjkljivo urejenih stanovanjskih območij veliko manj; razen v novih mestih.

Urbanost fizične strukture je bolje izražena $\mathrm{v}$ mestih mediteranskega kulturnega miljeja in v novih mestih, mesta v vzhodnem delu Slovenije pa so povečini manj strnjeno zazidana in z manjšimi gostotami, zato je stopnja urbanosti manjša.

\section{SKLEP}

Za fizično strukturo slovenskih mest je značilno:

1. nizka gostota zazidanosti in poseljenosti zaradi prevladujočih območij $\mathrm{s}$ prostostoječimi enostanovanjskimi hišami

2. kontrast med blokovnimi kompleksi in ostalim delom mesta, zazidanim s pretežno nizkimi, enodružinskimi hišami

3. prevladuje aditivni tip tlorisa

4. manjko površin socialnega pomena: trgov, javnih odprtih površin, urbanega zelenja

5. funkcionalistično prometno omrežje s premalo elementov bivalnega okolja

6. urbanost je v večini mest omejena zgolj na ožje in širše središče mesta

Na koncu želim opozoriti še na vprašljivost takšne interpretacije fizične strukture. Poleg izhodišča je lahko zgrešeno še pretirano posploševanje. Pri empirični obdelavi podatkov, še bolj pa pri interpretaciji, je bil vseskozi v ospredju problem načina objektivizacije rezultatov, oziroma o velikosti potrebnega vzorca, ki dovoljuje posploševanje rezultatov, metodolško sporni pa so lahko tudi kriteriji za opredeljevanje urbanosti. Metoda indukcije govori o t.i. verjetnostni hipotezi, po kateri je podobnost dejavnikov, ki razmere vzpostavljajo, pomembnejša od števila obravnavanih primerov. Kjer so dejavniki enaki, se vzpostavijo tudi podobne razmere (Sayer 1992 :157). Slednje nedvomno velja za mesta, ki se razvijajo v enakih ali zelo podobnih razmerah. Dodam naj še, da je namen prispevka opozoriti na skupne značilnosti fizične strukture slovenskih mest, ne pa značilnosti posameznih primerov; ali drugače: opozoriti na tiste prvine, zaradi katerih so slovenska mesta predvsem oskrbna in zaposlitvena središča, ne pa tudi kraj bivanja in kulture. 


\section{LITERATURA}

- $\quad$ Bertuglia Christoforo, Bianchi Giuliano, Mela Alfredo (Edit.): The City and Its Sciences. Berlin: Springer 1998

- Curdes Gerhard: Stadtstruktur und Stadtgestaltung. Stuttgart: Kohlhammer 1992

- Drozg Vladimir: Morfologija slovenskih mest. Ljubljana: Inštitut za geografijo 1998

- $\quad$ Franck Karen, Schneekloth Lynda (Edit.): Ordering Space. New York: Van Nostrand Reinhold 1994

- Hempert Klaus: Einführung in den Städtebau. Stuttgart. Kohlhammer 1997

- Koželj Janez: Strukturni pristop k skladnejši zidavi. V: Vesela znanost: o hišah, o mestih o podeželjih. Ljubljana: KUD France Prešeren 1993

- Koželj Janez: Degradirana urbana območja. Ljubljana: Urad za prostorsko planiranje 1998

- Mušič Vladimir: Urbanizem - bajke in resničnost. Ljubljana: Cankarjeva založba 1980

- Múler Wolfgang: Städtebau. Túbingen: Teubner 1979 (3. izdaja)

- Perfect Michael, Power Gordon: Planning for Urban Quality. London: Routledge 1997

- Pogačnik Andrej: Varstvo in usmerjanje oblikovne podobe slovenskih mest. Ljubljana: Urad za prostorsko planiranje 1996

- $\quad$ Sayer Andrew: Method in Social Science. London: Routledge 1992

\section{PHYSICAL STRUCTURE OF SLOVENE TOWNS}

\section{Summary}

This article deals with the urban aspects of the physical structure of Slovene towns. The relevant elements taken into consideration are: the density of the build-up areas (measured by the number of inhabitants per hectare), the type and height of the buildings in terms of the number of floors, the cross-section of traffic routes (measured by the proportion between traffic routes and pedestrian thoroughfare and tree-lined avenues), the type, distribution and location of squares, and the size and accessibility of parking lots. The findings are based on the analysis of 27 towns. The most important characteristics are the following:

1. The areas where the density exceeds 80 or 60 inhabitants per hectare are small in size. In big towns, they amount to a half or almost a half of the built-up areas, in the middle-sized towns between a quarter and a third of the built-up areas, and in small towns less than $10 \%$ of the built-up areas. This is due to a method of construction which does not allow for high density. While the density in blocks 
of flats may be even higher than 300 inhabitants per hectare, it amounts to only 40 inhabitants per hectare in single-family houses.

2. The most prevalent type of ground plan is that of the additive ground plan, which accounts for less uniform and at times even anarchic construction. Areas with more complex space design are rare.

3. The cross-section of traffic routes within residential areas is for the most part modest. In middle-sized towns there are $10 \%$ of traffic routes lined with trees or green areas and only $40 \%$ of traffic routes with pedestrian thoroughfare on average. The most urban in character are the traffic routes in the parts of town dating from the classicistic era, while in the more recent parts the traffic routes are designed as part of the technical system rather than as part of residential areas.

4. Squares usually serve as market places, as places for various performances and events, or are built around churches. Most medieval squares have a trade function, the ones from the classicistic era are usually parks or memorials, while the most recent squares serve primarily traffic purposes (crossroads or parking space). Many town sections have no morphological or social center. The squares have no infrastructure that would encourage a social function. The majority of them serve as parking areas, while the pedestrian areas are restricted. In terms of form, too, the squares are modest and only rarely include sculptures, fountains, vegetation and parks.

By superimposing graphic illustrations of individual morphological elements (i.e. buildings, traffic routes and squares) we defined areas with more strongly expressed urban character and those that lack urban character. It is concluded that the urban character is stronger in bigger towns than in smaller ones (with exceptions). There we find a greater proportion of specially designed and constructed residential areas and more diversity in the types of ground plans. The differences between the areas with sufficiently urban character and those without it are too great, as they range from 25 $\%$ to $80 \%$ of built-up areas. On average, the proportion of urban areas amounts to only $50 \%$.

Urban elements are concentrated in the very centers of the towns (in small towns) and in larger centers in middle-sized and bigger towns. In big towns, the urban character can be seen in most of the built-up areas except for the periphery and some areas with single-family houses built in the 1930s and after the 1970s. With almost no exception the most urban parts are medieval sections of towns, while more recent ones are less so because of the poorly regulated residential areas. Exceptions are some new towns. The urban character of the physical structure is more pronounced in the Mediterranean cultural milieu and in new towns, while most towns in the eastern part of Slovenia are usually less densely built-up and, consequently, show a lower degree of urbanity. 